\title{
Emotion Regulation Strategies as a Predictor of Life Satisfaction in University Students
}

\author{
Ahmet Yiğit1, Ahmet Ragıp Özpolat², Mehmet Kandemir ${ }^{3}$ \\ ${ }^{1}$ MertÖztüre Hearing Impaired Vocational Highschool, Ministry of National Education, İzmir, Turkey \\ ${ }^{2}$ Psychological Counseling and Guidance Department, Erzincan University, Erzincan, Turkey \\ ${ }^{3}$ Psychological Counseling and Guidance Department, Kırıkkale University, Kırıkkale, Turkey \\ Email: yigitahmet44@hotmail.com, ahmetozpolat@hotmail.com, mkandemir61@hotmail.com
}

Received 21 February 2014; revised 23 March 2014; accepted 16 April 2014

Copyright (C) 2014 by authors and Scientific Research Publishing Inc.

This work is licensed under the Creative Commons Attribution International License (CC BY).

http://creativecommons.org/licenses/by/4.0/

(c) (i) Open Access

\begin{abstract}
The goal of this research is to analyze the predictive power level of parent educational background, parent profession and suppression and reappraisal strategies, which are the emotion regulation strategies, on life satisfaction of individuals. Multiple Linear Regression model is used in the study whose research group is made of 422 students from a University, which has a total of 28,000 students, situated in the East of Turkey. Students in the research group are from different grades and demographic features. "Emotion Regulation Scale", "Satisfaction with Life Scale", and "Personal Information Form" are used in gathering the data of the research.
\end{abstract}

\section{Keywords}

\section{Emotion Regulation, Suppression, Reappraisal, Life Satisfaction}

\section{Introduction}

There has been an increasing interest in positive psychology concepts in recent years. Researches about concepts like happiness, hope, optimism, subjective wellbeing, motivation, academic success and life satisfaction have been increasing besides researches on some ignored concepts like emotion and emotion regulation. The science of psychology that analyses the problems of human beings such as unhappiness and mental health, has turned towards concepts like happiness, subjective wellbeing, life satisfaction (Diener, 1984), and emotion regulation (Öner, 1996; Gross, 1999; Çalışır, 2009). William James (1884) defines emotion as a kind of psychological and physical expression. Namely, he states that emotion is a pure mental situation. Gross (2002) defines emotion as a coordination of behavioral, empirical and psychological reaction tendencies which affect how we react when we are faced with opportunities and difficulties. Emotions serve to the life struggle of individual with their 
adaptable and protective features. A fast emotional response dominates individual in case of an emergency such as primal life and death struggle (Goleman, 2002). Namely, the way that an individual perceives danger shapes his emotional reactions (Atkinson, Atkinson, Smith, Bem, \& Hoeksema, 1996; Hilgard, Atkinson, \& Atkinson, 1975). Gross (1998a) defines emotion regulation as the state of electing which emotion to affect, how to experience and how to express. According to Thompson (1994), emotional regulation is made of internal and external processes which are in charge of monitoring, evaluating and changing emotional reactions. Emotional regulation includes increasing of emotional arousal and maintaining emotions besides suppression (Thompson, 1994). Gross (2002) mentions three views about the concept of Emotional Regulation: The first is "despite everything, individuals attempt to reduce negative emotions to minimum". Namely, individuals decrease negative emotions while increasing and maintaining positive emotions. The second view is "most of the Emotional Regulations such as deciding to change a sad issue should be carried out consciously" (Cole, 1986). The third is "Emotional Regulations are neither naturally good nor bad" (Smith \& Kleinman, 1989). Some researchers discuss emotion as a process (Frijda, 1986; Oatley \& Jenkins, 1996; Gross, 1998b). In Gross’s (2001) model, emotional regulation can be carried out at 5 points: 1) choice of situation, 2) changing situation, 3) distraction 4) changing cognition and e) changing experimental, behavioral and psychological reactions. Gross (1998b) mentions two special emotion regulation strategies as reappraisal and suppression strategies. Reappraisal is a cognitive change style and it is reinterpreting Reappraisal decreases emotional effect of reaction. Suppression strategy, on the other hand, is a kind of changing reaction and it is reaction-oriented. The concept of suppression used here means suppressing the behavior of expressing ongoing emotions (Gross \& Levenson, 1997). In their research, Gross and John (2003) found that reappraisal is related to experiencing positive emotions. They stated that there are individual differences in emotional regulation's reappraisal and suppression strategies. Gross and Levenson (1997) analyzed the effect of emotion regulation on mental health and reported that meaningful behaviors decreased in the group who suppressed emotions; cheerfulness decreased while watching both melancholic and entertaining movies. In his research, Şarlak (2008) analyzed emotion-personality relation and found that there was a positive relation between outwardness, being open for improvement dimension of - personality typesand positive emotions; there was a negative relation between amiableness and negative relations. Çalışır (2009) determined that individuals that have different attachment styles are different from one another in terms of emotional reactions and what they do in line with these emotions. Lü and Wang (2012) made a comparative research on different ethnic groups and they found that negative statement scores of Tibetan university students were higher than the others and emotion regulation scores of Hanlar students were higher than the others. On the other hand, there are many studies on the issue of the relation between emotions and facial expressions (Ekman, 1984; Ekman, 1992; Ekman, 1993; Russell, 1994; Kring \& Gordon, 1998). Concepts like life satisfaction, subjective well being and life quality are sometimes used instead of happiness (Bekhet, Zauszniewski, \& Nakhla, 2008; Lu, 2000). While the concept of happiness is mostly used in the field of philosophy, researchers in the field of psychology prefer subjective wellbeing. But life satisfaction is different from both concepts in many ways. For instance, while happiness is used for objective wellbeing, life satisfaction mostly stands for subjective judgment (Kümbül-Güler \& Emeç, 2006). In life satisfaction, an individual makes a detailed and general evaluation about his life (Veenhoven, 1996). Throughout history, philosophers defined happiness as the highest wellbeing of human action and ultimate motivation (Diener, 1984). Subjective wellbeing is generally defined as satisfaction in life and having positive relations more than negative relations (Diener, 1984). In other words while Diener and Diener (1995) define life satisfaction, which is the cognitive component of subjective wellbeing, as an individual's appraising various fields in life, Shin and Johnson (1978) define the same concept as an individual's holistic point of view about life quality according to chosen criteria. Namely, life satisfaction is an indicator of an individual's satisfaction level about his life (Veenhoven, 1996). Andrews and Withey (1976) defined three different components of subjective wellbeing (Trans. Diener, 1985): Positive emotion, negative emotion and life satisfaction. The first two factors are the affective dimension of subjective wellbeing (Diener, 1985) while the third factor, life satisfaction, is the cognitive dimension (Diener, 1985; Diener, Emmons, Larsen, \& Griffin, 1985). Life satisfaction is about cognitive evaluation processes and is based on evaluating of satisfaction and an individual's comparing himself with the standard proper conditions that he believes (Diener, Emmons, Larsen, \& Griffin, 1985). An individual's self-evaluation is significant in the field of subjective wellbeing, because values such as health, strength and attraction can vary from one individual to another. Diener and Oishi (2004) found that being happy is more important than being healthy, having high income and being highly attractive. In the researches on the field (Gitmez \& Morçöl, 1994; Lucas, Diener, \& Suh, 1996; Bekhet, Zauszniewski, \& Nakhla, 
2008) there were found to be meaningful relations between happiness and life satisfaction. It is known that life satisfaction has positive effects on human health, positive interpersonal relations and success. It was determined that there are meaningful relations between life satisfaction, positive emotion, negative emotion and depression (Durak, Senol-Durak, \& Gençöz, 2010). In the research by Kümbül-Güler and Emeç (2006), they determined that optimism and life satisfaction are related to one another. The research of Aka (2011) showed the relations of different parent attitudes, emotion regulation styles and processes of depression, obsessive compulsive disorder and social anxiety symptoms. In the research of Özbay, Palanc1, Kandemir and Çakır (2012), regulating emotions (cognitive restructuring) was the most significant variable in the research model that predicted subjective wellbeing.

Literature review exposes research studies about affective domain parameters related with various psychological factors as well as some other studies about life satisfaction effected by depression and emotional levels. It can be seen that there is not enough reliable information available relating affective regulation strategies with life satisfaction whereas regulating emotions is a precursor for a fulfilled life (Ellis, 1962). Life satisfaction studies widely discuss that depression is accounted for individual's emotions. Life is not satisfied when an individual cannot regulate their feelings. The works in literature heavily address different variables of emotions rather than individual's emotional regulation skills. Current study can be considered as an addition to meet this gap in the literature. Life satisfaction studies have mostly targeted western culture where individualism is much more widespread. In individualized societies, a person feels less shyness in expressing feelings since being an individual is encouraged from the childhood. Collective societies, on the other hand, being a member of society is more highlighted than being perceived as individuals. An individual may not be comfortable expressing him/ herself in favor of society since collective life is more emphasized than acting individually (Markus \& Kitayama, 1991). This study focuses on a sample from Turkish society which is largely structured as a collective society, and this aspect can be a valuable contribution to the literature.

Happiness, subjective wellbeing and life satisfaction, is a topic that should be researched from many dimensions, and new researches are necessary on this issue. The goal of this study, which will hopefully make contribution to the researches about life satisfaction in Turkey, is to research emotion regulation strategies as a predictor of life satisfaction. Answers to the below mentioned questions are attempted to be found:

1) Do emotion regulation strategies of university students differ according to parents' profession, educational background and income level?

2) What is the prediction power of suppression and reappraisal dimensions of emotion regulation strategies and parent profession, educational background and income level on the issue of life satisfaction?

\section{Method}

\subsection{Sample}

Multiple Linear Regression model was used in the research which analyzed the predictive power of suppression and reappraisal strategies, parent educational background, parent profession and family income level on life satisfaction of individuals. According to Karasar (2005), Multiple Linear Regression model is a research model that aims at determining the existence and level of covariance between two or more variables. The research group was made of 422 students of a university, which has a total of 28,000 students. In scope of the research, 184 (43.6\%) male and 277 (56.4\%) female students participated in the research with proper sampling method. Participants' income levels were; 144 participants (34.1\%) below 1000 TL, 224 participants (53.1\%) between 2000 and 3000 TL and 54 (12.8\%) between 3000 and 5000 TL. Ages of participants were; 198 (46.9\%) students between 18 and 20 and 224 students (53.1\%) between 21 and 24. Students' parents' profession in the study group were; mothers of 345 (83.1\%) students were unemployed, mothers of 20 (4\%) students were workers, mothers of $28(6 \%)$ students were officer and mothers of 29 (6.9\%) students were shopkeeper. Fathers of 89 students were (21.1\%) retired, fathers of 102 (24.1\%) students were officer, fathers of 66 (15.6\%) students were worker, fathers of 81 (19.2\%) students were shopkeeper, fathers of 61 (14.5\%) students were farmer, and fathers of 23 (5.5\%) students were unemployed. Parent education level of participators were; mothers of 100 (23.7\%) students were illiterate, mothers of 46 (10.9\%) students were literate, mothers of 158 (37.5\%) students were illiterate, mothers of 38 (9\%) students were secondary school graduate, mothers of 58 (13.7\%) students were high school graduate and mothers of 22 (5.2\%) students were university graduate. Fathers of 22 students (5.2\%) were illiterate, fathers of 27 (6.4\%) students were literate, fathers of 127 (30.2\%) students were primary school graduate, 
fathers of 101 (23.9\%) students were high school graduate, fathers of 71 (16.8\%) students were secondary school graduate, fathers of 74 (17.5\%) students were university graduate.

\subsection{Data Collection Tools}

In order to determine life satisfaction levels of students, Satisfaction with Life Scale developed by Diener, Emmons, Laresen and Griffin (1985); Emotion Regulation Scale developed by Gross and John (2003) and Personal Information form, developed by the researchers in order to gather data about independent variables, were used in this study.

\subsubsection{Satisfaction with Life Scale-SWLS}

Satisfaction with Life Scale is developed by Diener, Emmons, Laresen and Griffin (1985) in order to evaluate general life satisfaction and it is made of 5 items. It is a likert type scale whose items are graded between 1 and 7 . Diener et al. (1985) determined that internal consistency of the scale is 0.87 and test retest reliability coefficient of the scale is 0.82. Turkish adaptation of the scale was made by Köker (1991), Yetim (1993) and Durak, SenolDurak and Gençöz (2010). At the end of the reliability studies made by Durak, Senol-Durak and Gençöz (2010), it was determined that, test retest reliability coefficient of the scale, which had been conducted twice in three weeks, was .85. On the other hand, while Cronbach Alpha reliability coefficient of the scale was found to be .76 at the beginning, it was determined to be .82 in the second application.

\subsubsection{The Emotion Regulation Questionnaire-ERQ}

The questionnaire was developed by Gross and John (2003) in order to determine emotion regulation strategies. The scale is made of two parts as Cognitive reappraisal and Suppression. The items of the scale, which is a likert type scale, can be graded between 1 and 7. In terms of the reliability of the questionnaire; internal consistency coefficient was found to be .79 for Cognitive reappraisal, .73 for Suppression. Test retest reliability coefficient was found to be .69 for both sub scales (Gross \& John, 2003). The adaptation of the scale to Turkish was made by Şarlak (2008) and Yurtsever (2008). At the end of the factor analysis carried out by Şarlak (2008), it was determined that items were divided into two sub factors. The obtained factors explained $46.89 \%$ of the variance of emotional regulation. In his study, Yurtsever (2008) determined that Cronbach Alpha internal consistency for Cognitive reappraisal was .85 while it was .78 for Emotional suppression. Test retest reliability coefficient of the scale was .88 for Cognitive reappraisal, .82 for Emotional suppression (Yurtsever, 2008).

\subsubsection{Personal Information Form}

Data about the independent variables of the research was obtained by Personal information form developed by the researcher. With this form, information about sex, age, class, perceived academic success, economic condition, mother-father profession, mother-father educational background, were determined.

\section{Findings}

In this section of this study, One Way ANOVA test, about the sub problem of "Do the emotion regulation strategies of university students vary according to parent profession, educational background and income level?" was carried out and the results are presented.

One Way ANOVA test results of the sub problem of "Do the emotion regulation strategies of university students vary according to parent profession, educational background and income level?”

When Table 1 is analyzed, it can be seen that suppression, which is one of the emotion regulation strategies, varies according to mother profession. LSD test was conducted in order to determine the differences among groups and results are presented in Table 2.

When Table 2 is analyzed, it can be seen that mother of individuals who use suppression strategy while regulating emotions, do not work. On the other hand, individuals whose mother is worker use suppression strategy more while regulating emotions when compared to individuals whose mother is shopkeeper.

When Table 3 is analyzed, it can be seen that university students' emotion regulation strategies don't vary according to father profession.

When Table 4 is analyzed, it can be seen that suppression, which is one of the emotion regulation strategies of university students, varies according to mother educational background. LSD test was conducted in order to 
Table 1. Results of one way ANOVA test about "Do the emotion regulation strategies of university students vary according to mother profession?”

\begin{tabular}{|c|c|c|c|c|c|c|}
\hline & & Sum of Squares & df & Mean Square & $\mathrm{F}$ & Sig. \\
\hline \multirow{3}{*}{ Suppression } & Between Groups & 877.566 & 7 & 125.367 & $3.967^{* *}$ & $.001^{* *}$ \\
\hline & Within Groups & 12355.201 & 415 & 31.599 & & \\
\hline & Total & 13232.767 & 422 & & & \\
\hline \multirow{3}{*}{ Reappraisal } & Between Groups & 684.739 & 7 & 97.820 & 2.028 & .051 \\
\hline & Within Groups & 19247.708 & 415 & 48.240 & & \\
\hline & Total & 19932.447 & 422 & & & \\
\hline
\end{tabular}

Note: ${ }^{* *} p<.001$.

Table 2. Findings about the source of difference in terms of mother profession of university students.

\begin{tabular}{cccc}
\hline & (I) Mother Profession & (J) Mother Profession & Mean Difference (I-J) \\
\hline Mother Profession & Not Working & Officer & $-3.96858^{* *}$ \\
Mother Profession & Worker & Shopkeeper & $-6.37965^{* *}$ \\
.001 & Shopkeeper & $-5.20000^{*}$ \\
\hline
\end{tabular}

Note: ${ }^{*} p<.05 ; \stackrel{* *}{p}<.001$.

Table 3. Results of one way ANOVA test about "Do the emotion regulation strategies of university students vary according to father profession?”

\begin{tabular}{|c|c|c|c|c|c|c|}
\hline & & Sum of Squares & df & Mean Square & $\mathrm{F}$ & Sig. \\
\hline \multirow{3}{*}{ Suppression } & Between Groups & 300.043 & 7 & 37.505 & 1.132 & .340 \\
\hline & Within Groups & 12750.173 & 415 & 33.117 & & \\
\hline & Total & 13050.216 & 422 & & & \\
\hline \multirow{3}{*}{ Reappraisal } & Between Groups & 192.822 & 7 & 24.103 & .492 & .862 \\
\hline & Within Groups & 19255.447 & 415 & 48.996 & & \\
\hline & Total & 19448.269 & 422 & & & \\
\hline
\end{tabular}

Table 4. Results of One Way ANOVA test about "Do the emotion regulation strategies of university students vary according to mother educational background?”

\begin{tabular}{ccccccc}
\hline & & Sum of Squares & df & Mean Square & F & Sig. \\
\hline \multirow{2}{*}{ Suppression } & Between Groups & 517.235 & 7 & 86.206 & $2.657^{*}$ & $.015^{*}$ \\
& Within Groups & 12878.557 & 415 & 32.440 & & \\
& Total & 13395.792 & 422 & & .476 & .826 \\
& Between Groups & 143.433 & 7 & 23.905 & & \\
Reappraisal & Within Groups & 20325.798 & 415 & 50.187 & & \\
\hline
\end{tabular}

Note: ${ }^{*} p<.05$. 
determine the differences among groups in terms of mother educational background of university students, and results are presented in Table 5 .

When Table 5 is analyzed, it can be seen that mother of individuals who use suppression, which is one of the emotion regulation strategies, are not literate and there is a decrease in the use of suppression strategy in parallel with the increase in educational level.

When Table 6 is analyzed, it can be seen that emotion regulation strategies of university students don't vary according to father educational background.

ANOVA Test result of regression analysis of the research question "Prediction level of Suppression and Reappraisal, which are emotion regulation strategies, parent profession, educational background and income level, on life satisfaction" are presented in Table 7.

Results of One Way ANOVA test, which tested the meaningfulness of the regression model, formed for the predictive power of the variables of Suppression, Reappraisal, parent profession, educational background and income levels, are presented in Table 8 . According to the test, the model is generally meaningful $\left(\mathrm{F}_{(7-422)} 15,939\right.$ $p<.001)$.

The regression equality (mathematical model) about the predictive power of the variables of Suppression, Reappraisal, parent profession, parent educational background and parent income level of university students on Life Satisfaction, according to the regression analysis results, is presented below.

Life Satisfaction $=$ Reappraisal. .324 + Income, .120 + Mother Education, .135 + Father Education, .118

Table 5. Findings about the source of difference in terms of mother educational background of university students.

\begin{tabular}{lccc}
\hline Dependent Variable & (I) Mother Education & (J) Mother Education & Mean Difference (I-J) \\
\hline & Illiterate & $4.13684^{* *}$ & .001 \\
Mother Education Level & University & Elementary School & $4.72902^{* *}$ \\
.001 & Secondary School & $4.63743^{* *}$ & $3.56140^{* *}$ \\
\hline
\end{tabular}

Note: ${ }^{* *} p<.001$

Table 6. Results of one way ANOVA test about "Do the emotion regulation strategies of university students vary according to father educational background?

\begin{tabular}{ccccccc}
\hline & Sum of Squares & df & Mean Square & F & Sig. \\
\hline \multirow{3}{*}{ Suppression } & Between Groups & 328.356 & 7 & 46.908 & 1.427 & .193 \\
& Within Groups & 12849.288 & 415 & 32.863 & & \\
Total & 13177.644 & 422 & & .828 & .565 \\
& Between Groups & 289.228 & 7 & 41.318 & & \\
& Within Groups & 19862.683 & 415 & & & \\
\hline
\end{tabular}

Table 7. One way ANOVA test results of regression model about suppression, reappraisal, parent profession, educational background and income level.

\begin{tabular}{rrcccc}
\hline \multicolumn{2}{c}{ Model } & Sum of Squares & df & Mean Square & F \\
\hline Regression & 4772.924 & 7 & 681.846 & $15.939^{* *}$ \\
Residual & 15399.815 & 415 & 42.777 \\
Total & 20172.739 & 422 & & .001 \\
& & & & \\
\end{tabular}

Note: ${ }^{* *} p<.001$. 
Table 8. Multiple linear regression analysis results about suppression, reappraisal, parent profession, educational background and income level.

\begin{tabular}{|c|c|c|c|c|c|c|}
\hline & \multirow{2}{*}{ Model } & \multicolumn{2}{|c|}{ Non-standardized Coefficients } & \multirow{2}{*}{$\begin{array}{c}\text { Standardized Coefficients } \\
\text { Beta }\end{array}$} & \multirow{2}{*}{$\mathrm{t}$} & \multirow{2}{*}{ Sig. } \\
\hline & & B & Std. Error & & & \\
\hline \multirow{9}{*}{1} & (Constant) & 3.869 & 1.980 & & 1.954 & .051 \\
\hline & Suppression & .082 & .063 & .064 & 1.304 & .193 \\
\hline & Reappraisal & .342 & .050 & .324 & $6.797^{* * *}$ & .001 \\
\hline & Mother Profession & .285 & .263 & .056 & 1.082 & .280 \\
\hline & Father Profession & -.222 & .169 & -.061 & -1.313 & .190 \\
\hline & Income & 1.193 & .510 & .120 & $2.338^{*}$ & .020 \\
\hline & Mother edu. & .664 & .309 & .135 & $2.145^{*}$ & .033 \\
\hline & Father edu. & .590 & .300 & .118 & $1.970^{*}$ & .050 \\
\hline & & & R2: .237 & & & \\
\hline
\end{tabular}

Note: ${ }^{*} p<.05 ;{ }^{* *} p<.001$.

It can be seen that the variables of Reappraisal, Income, Mother Education, and Father Education are predictors of life satisfaction. It is seen that, Reappraisal predicts $32.4 \%$, Income, $12 \%$, Mother education explains and predicts $13.5 \%$, Father education explains and predicts $11.8 \%\left(\mathrm{R}^{2}: .237\right)$.

\section{Discussion}

The goal of this study is to research if emotion regulation strategies vary according to parent profession, educational background and income level and to determine the prediction power of suppression, reappraisal dimensions of emotion regulation strategies, parent profession, parent educational background and parent income level on life satisfaction; at the end of the researches, it was determined that reappraisal strategy, parent profession, educational background and income level directly predict life satisfaction. When the similar researches, which support the result of this study, in the literature are analyzed, it can be seen that Özbay, Palanc1, Kandemir and Çakır (2012) found that the most significant predictive variable of subjective wellbeing of university students is emotion regulation (cognitive restructuring). There is a positive relation between life satisfaction and emotion regulation. Gross and John (2003) determined that reappraisal, which is one of the emotion regulation strategies, is related to experiencing positive emotions. Gross and Levenson (1997) made a research on the effect of emotion regulation on mental health and they reported that there was a decrease in happiness and meaningful behaviors of the group that suppressed emotions. In Aka's (2011) research, he showed the relations of different parent attitudes, emotion regulation styles and processes of depression, obsessive compulsive disorder and social anxiety symptoms. In this research, it was determined that suppression, which is one of the emotion regulation strategies of university students, varies according to mother profession and educational background. It was seen that mother of individuals who use suppression strategy while regulating emotions do not have a profession, namely they don't work. On the other hand, it was found that individuals whose mother is worker use suppression strategy more while regulating emotions when compared to the individuals whose mother is shopkeeper. It was seen that children use suppression strategy less when the role and the point of view about women change, and when women have a voice in business life. It was also understood that mothers of individuals who use suppression, are not literate and the increase in educational level of mother causes decrease in the use of suppression strategy. There is a relation between profession, the ability level required by that profession and educational level. When the behaviors to be learnt become more difficult and complicated, the necessary level of ability also increases (Kuzgun, 2000). Women, whose educational level increase, have better chance to acquire a profession and get a start in business. Based on this point of view, it wouldn't be wrong to say that educational level of working women is higher. There are studies showing that when education level increases, parents adopt more democratic attitudes (Kaya, Bozaslan, \& Genç, 2012), there is a positively meaningful relation between mother attitude and empathetic tendency (Kurbet, 2010) and there is a meaningful relation between mother educational 
level and child's problem solving ability (Yalçın, Tetik, \& Açıkgöz, 2010). In a sense, it can be said that, parents' abilities of child rearing, problem solving and creating effective communication increase with education. In their research, Kaya, Bozaslan and Genç (2012) determined that parents who have high education level have democratic attitudes, their children's problem solving ability is high and social anxiety is low. It is known that mother and father are effective in personality development, problem solving and communication abilities of children. Yalçın, Tetik and Açıkgöz (2010) determined that there is a meaningful difference between mother's educational background and having confidence in problem solving ability. Mothers whose education level is high, support their children in terms of expressing thoughts and emotions freely, having high self esteem, having confidence in making his/her own decisions (Yiğit, 2005) and being successful individuals. According to Kurbet's study (2010), there is meaningful difference between children's emotional regulation according to mother's empathetic tendency. Kurbet found that there is meaningful difference between children's emotional regulation scores according to mother attitude and there is a positive and highly meaningful relation between supportive mother attitude scores and empathetic tendency scores. These results support the results of this study. In the research, it was seen that emotion regulation strategies of university students don't vary according to father profession. Similarly, in the research by Yalçın, Tetik and Açıkgöz (2010), they found that the factor of having confidence in problem solving ability in terms of father education level, doesn't meaningfully vary. We know that mother-child relation starts before birth, and continues quite strongly after it. The effects of this strong connection on child are indisputable. Interaction between father and child is more limited when compared to mother-child relation. It was determined that reappraisal strategy, one of the emotion regulation strategies of students, parent educational background, parent profession and income level directly predict life satisfaction. In this context, individuals who use reappraisal are more satisfied with their life. In fact, strategies that are used while expressing feelings reflect personality structure. The study by Hosseinkhanzadeh \& Taher (2013) also shows that there is a relation between personality structures and life satisfaction. Based on the findings of the study, it can be said that a child's ability to express himself increases and he/she has a more satisfactory life when parents' education level increases, the level of income increases and the communication style develops in parallel with these changes. As a result, it was determined that reappraisal strategy, which is one of the emotion regulation strategies, parent educational background, parent profession and income level, directly predict life satisfaction .23. But the data obtained in this study are limited to demographic variables of individuals and their parents and there are many variables that explain life satisfaction. It is believed that researches analyzing these variables and different studies including the analysis of data obtained with both qualitative and quantitative scales can make more contributions to the field.

\section{Conculsion}

Life satisfaction, in various age groups and with different variables in different cultures should be investigated. Emotion regulation is one of the important indicators of life satisfaction and new studies are needed. Indeed, there is a meaningful relation between life satisfaction and emotion regulation (Gross \& John, 2003). Research findings about the mother's role in emotion regulation in general shows that large (Kurbet, 2010). The parents have a major influence in an individual's life skills, problem solving skills (Yalçın, Tetik, \& Açıkgöz, 2010), the self-confidence, social skills and emotion regulation strategies. These variables directly and indirectly affect life satisfaction.

The methods of growing up high life satisfaction generations should be investigated. However, with researches focused only on the individual but also to focus on parents that educate generations of researches are needed. In parents educations, family and marriage counseling sand psycho education programs, especially given priority to the development of these features of the parents. Improving economic and educational level of the family directly and indirectly will affect children in a positive way. For example, there is a meaningful positive relation between mothers' attitudes and empathic tendencies (Kurbet, 2010) that are known. In order to benefit from educational opportunities of girls, special effort should be made. Development policies and strategies in this regard should be fully implemented. The share of women in business should be increased and active participation in business life can be achieved. Happy families educate happy individual.

\section{References}

Aka, B. T. (2011). Perceived Parenting Styles, Emotion Recognition, and Emotion Regulation in Relation to Psychological 
Well-Being: Symptoms of Depression, Obsessive-Compulsive Disorder, and Social Anxiety. Yayımlanmamış Doktora Tezi, Ankara: Orta Doğu Teknik Üniversitesi, Sosyal Bilimler Enstitüsü.

Andrews, F. M., \& Withey, S. B. (1976). Socialindicators of Well-Being: America's Perception of Life Quality. New York: Plenum.

Atkinson, R. L., Atkinson, R. C., Smith, E. E., Bem, D. J., \& Hoeksema, S. N. (1996). Psikolojiye girişs (12th ed.). Çev. Yavuz Alagon. Ankara: Arkadaş Yayınları, s. 395.

Bekhet, A. K., Zauszniewski, J. A., \& Nakhla, W. E. (2008). Happiness: The Oretical and Empirical Considerations. Nursing Forum, 43, 12-23.

Cole, P. M. (1986). Children’s Spontaneous Control of Facial Expression. Child Development, 57, 1309-1321. http://dx.doi.org/10.2307/1130411

Çalışır, M. (2009). Yetişkin bağlanma kuramı ve duygulanım düzenleme stratejilerinin depresyonla ilişkisi. Psikiyatride Güncel Yaklaşımlar, 1, 240-255.

Diener, E. (1984). Subjective Well-Being. Psychological Bulletin, 95, 542-575. http://dx.doi.org/10.1037/0033-2909.95.3.542

Diener, E. (1995). A Value Based İndex for Measuring National Quality of Life. Social Indicators Research, 36, $107-127$. http://dx.doi.org/10.1007/BF01079721

Diener, E., \& Diener, M. (1995). Cross-Cultural Correlates of Life Satisfaction and Self-Esteem. Journal of Personality and Social Psychology, 68, 653-663. http://dx.doi.org/10.1037/0022-3514.68.4.653

Diener, E., \& Oishi, S. (2004). Are Scandinavians Happier than Asians? Issues in Comparing Nations on Subjective WellBeing. In F. Columbus (Ed.), Asian Economic and Political İssues: Vol. 10 (pp. 1-25). Hauppauge, NY: Nova Science.

Diener, E., Emmons, R. A., Larsen, R. J., \& Griffin, S. (1985). The Satisfaction with Life Scale. Journal of Personality Assessment, 49, 71-75.

Durak, M., Senol-Durak, E., \& Gencoz, T. (2010). Psychometric Properties of the Satisfaction with Life Scale among Turkish University Students, Correctional Officers, and Elderly Adults. Social Indicators Research, 99, 413-429. http://dx.doi.org/10.1007/s11205-010-9589-4

Ekman, P. (1984). Expression and the Nature of Emotion. In K. Scherer \& P. Ekman (Eds.), Approaches to Emotion (pp. 319-344). Hillsdale, NJ: Lawrence Erlbaum.

Ekman, P. (1992). An Argument for Basic Emotions. Cognition and Emotion, 6, 169-200.

Ekman, P. (1993). Facial Expression and Emotion. American Psychologist, Journal of Personality and Social Psychology, 48, 384-392. http://dx.doi.org/10.1037/0003-066X.48.4.384

Ellis, A. (1962). Reasonand Emotion in Psychotherapy. New York: Lyle Stuart.

Frijda, N. H. (1986). The Emotions. Cambridge: Cambridge University Press.

Gitmez, A. S., \& Morçöl, G. (1994). Socio-Economic Status and Life Satisfaction in Turkey. Social Indicators Research, 31, 77-98. http://dx.doi.org/10.1007/BF01086515

Goleman, D. (2002). Duygusal zeka: Neden IQ’dan daha önemlidir. İstanbul: Varlık Yayınları, s. 365.

Gross, J. J. (1998a). Antecedent- and Response-Focused Emotion Regulation: Divergent Consequences for Experience, Expression, and Physiology. Journal of Personality and Social Psychology, 74, 224-237. http://dx.doi.org/10.1037/0022-3514.74.1.224

Gross, J. J. (1998b). The Emerging Field of Emotional Regulation: An İntegrative Review. Review of General Psychology, 2, 271-299. http://dx.doi.org/10.1037/1089-2680.2.3.271

Gross, J. J. (1999). Emotion Regulation: Past, Present, Future. Cognition \& Emotion, 13, 551-573. http://dx.doi.org/10.1080/026999399379186

Gross, J. J. (2001). Emotion Regulation in Adulthood: Timing Is Everything. Current Directions in Psychological Science, 10, 214-219. http://dx.doi.org/10.1111/1467-8721.00152

Gross, J. J. (2002). Emotion Regulation: Affective, Cognitive, and Social Consequences. Psychophysiology, 39, $281-291$. http://dx.doi.org/10.1017/S0048577201393198

Gross, J. J., \& John, O. P. (2003). Individual Differences in Two Emotion Regulation Processes: Implications for Affect, Relationships, and Well-Being. Journal of Personality and Social Psychology, 85, 348-362. http://dx.doi.org/10.1037/0022-3514.85.2.348

Gross, J. J., \& Levenson, R. W. (1997). Hiding Feelings: The Acute Effects of Inhibiting Negative and Positive Emotion. Journal of Abnormal Psychology, 106, 95-103. http://dx.doi.org/10.1037/0021-843X.106.1.95

Hilgard, E. R., Atkinson, R. C., \& Atkinson, R. L. (1975). Introduction to Psychology (6th ed.). USA: Harcourt Brace Jovanovich Inc., 351. 
Hosseinkhanzadeh, A., \& Taher, M. (2013). The Relationship between Personality Traits with Life Satisfaction. Sociology Mind, 3, 99-105. http://dx.doi.org/10.4236/sm.2013.31015

James, W. (1884). What Is an Emotion? Mind, 9, 188-205. http://dx.doi.org/10.1093/mind/os-IX.34.188

Karasar, N. (2005). Bilimsel Araştırma Yöntemi. Ankara: Nobel Yayın Dağıtım.

Kaya, A., Bozaslan, H., \& Genç, G. (2012). Üniversite öğrencilerinin anne baba tutumlarının problem çözme becerilerine, sosyal kaygı düzeylerine ve akademik başarılarına etkisi. Dicle Üniversitesi Ziya Gökalp Eğitim Fakültesi Dergisi, 18, 208-225.

Köker, S. (1991). Normal ve sorunlu ergenlerin yaşam doyumu düzeyinin karşılaştırılması. Ankara: Yayımlanmamış Yüksek Lisans Tezi, Ankara Üniversitesi, Sosyal Bilimler Enstitüsü.

Kring, A. M., \& Gordon, A. H. (1998). Sex Differences in Emotion: Expression, Experience, Andphysiology. Journal of Personality and Social Psychology, 74, 686-703. http://dx.doi.org/10.1037/0022-3514.74.3.686

Kurbet, H. (2010). Anaokuluna devam eden çocukların duygusal düzenleme becerileri ile annelerinin empatik eğilim ve tutumlarının incelenmesi. Gazi Üniversitesi-Eğitim Bilimler Enstitüsü-Çocuk Gelişimi Bölümü-Çocuk Gelişimi ve Eğitimi Anabilim Dalı-Çocuk Gelişimi ve Eğitimi Bilim Dalı. Yayımlanmamış Yüksek Lisans Tezi.

Kuzgun Y. (2000). Meslek danışmanlığl: kuramlar, uygulamalar. Ankara: Nobel Yayınları.

Kümbül-Güler, B., \& Emeç, H. (2006). Yaşam memnuniyeti ve akademik başarıda iyimserlik etkisi. D.E.Ü.İ.İ.B.F. Dergisi Cilt:21 Say1:2, 129-149.

Lu, L. (2000). Gender and Conjugal Differences in Happiness. Journal of Social Psychology, 140, 132-141. http://dx.doi.org/10.1080/00224540009600451

Lucas, R. E., Diener, E., \& Suh, E. (1996). Discriminant Validity of Well-Being Measures. Journal of Personality and Social Psychology, 71, 616-628. http://dx.doi.org/10.1037/0022-3514.71.3.616

Lü, W., \& Wang, Z. (2012). Emotional Expressivity, Emotional Regulation, and Mood in College Students: A Cross-Ethnic Study. Social Behavior and Personality, 40, 319-330.

Markus, H. R., \& Kitayama, S. (1991). Culture and the Self: Implications for Cognition, Emotion and Motivation. Psychological Review, 98, 224-253. http://dx.doi.org/10.1037/0033-295X.98.2.224

Oatley, K., Keltner, D., \& Jenkins, J. M. (1996). Understanding Emotions (2nd ed.). Hoboken: Blackwell Publishing.

Öner, N. (1996). Psikolojik danışmanlıkta yeni ufuklara bir örnek: Duyuşsalzeka. 9. ulusal psikoloji kongresi. Istanbul: BogaziçiÜni, s. 191.

Özbay, Y., Palancı, M., Kandemir, M., \& Çakır, O. (2012). Üniversite öğrencilerinin öznel iyi oluşlarının duygusal düzenleme, mizah, sosyal özyeterlilik ve başaçıkma davranışları ile yordanması. Türk Eğitim Bilimleri Dergisi. Bahar, 10, 325-345.

Russell, J. A. (1994). Is There Universal Recognition of Emotion from Facial Expression? A Review of the Cross-Cultural Studies. Psychological Bulletin, 115, 102-141. http://dx.doi.org/10.1037/0033-2909.115.1.102

Shin, D. C., \& Johnson, D. M. (1978). Avowed Happiness as an Overal Lassessment of the Quality of Life. Social Indicators Research, 5, 475-492. http://dx.doi.org/10.1007/BF00352944

Smith, A. C., \& Kleinman, S. (1989). Managing Emotions in Medical School: Students' Contacts with the Living and the Dead. Social Psychology Quarterly, 52, 56-69.

Şarlak, K. (2008) Duygusal yaşantılarda ve duygusal düzenlemede gözlenen bireysel farkl1lıkların çok boyutlu olarak değerlendirilmesi. Muğla Üniversitesi-Sosyal Bilimler Enstitüsü-Psikoloji Bölümü-Psikoloji Anabilim Dalı. Yayımlanmamış Yüksek Lisans Tezi.

Thompson, R. A. (1994). Emotion Regulation: A Theme in Search of Definition. Monographs of the Society for Research in Child Development, 59, 25-52. http://dx.doi.org/10.2307/1166137

Veenhoven, R. (1996). The Study of Life Satisfaction. In W. E. Saris, R. Veenhoven, A. C. Scherpenzeel, \& B. A Bunting (Ed.), Comparative Study of Satisfaction with Life in Europ (pp. 11-48). Budapes: Eötvös University Press.

Yalçın, B., Tetik, S., \& Açıkgöz, A. (2010). Yüksekokul öğrencilerinin problem çözme becerisi algıları ile kontrol odağı düzeylerinin belirlenmesine yönelik bir araştırma. Organizasyon ve Yönetim Bilimleri Dergisi. Cilt 2, Say1 2, 19.

Yetim, Ü. (1993). Life Satisfaction: A Study Based on the Organization of Personal Projects. Social Indicators Research, 29, 277-289. http://dx.doi.org/10.1007/BF01079516

Yiğit, A. (2005). Lise öğrencilerinin karar verme davranışlarının bazı değişkenlere göreyordanması. Ege Üniversitesi- Sosyal Bilimler Enstitüsü-Rehberlik ve Psikolojik Danışmanlık Bilim Dalı. Yayımlanmamış Yüksek Lisans Tezi.

Yurtsever, G. (2008). Negotiators’ Profit Predicted by Cognitive Reappraisal, Suppression of Emotions, Misrepresentation of Information, and Tolerance of Ambiguity. Perceptualand Motor Skills, 106, 590-608.

http://dx.doi.org/10.2466/pms.106.2.590-608 